\title{
HOZZÁSZÓLÁS \\ A TÉR ÉS TÁRSADALOM CÍMÜ FOLYÓIRAT REHABILITÁCIÓRÓL SZÓLÓ SPECIÁLIS SZÁMÁNAK BEMUTATÁSA SORÁN SZERVEZETT VITÁHOZ
}

\section{HEGEDÜS JÓZSEF HOZZÁSZÓLÁSA}

Örömmel láttam a Tér és Társadalom városrehabilitációval foglalkozó különszámát, hiszen a téma nemcsak érdekes, több tudományterületet keresztező kutatási probléma, hanem egy súlyos, aktuális városfejlesztési konfliktusterület is. Hozzászólásomban nem tudom részleteiben elemezni az egyes tanulmányokat. Mindenesetre megállapítható, hogy a kötet jó keresztmetszetét adja a hazai rehabilitációt vizsgáló kutatások eredményeinek, bár jól kiegészítette volna a válogatást egy írás a több tanulmány által idézett - „,szociális” rehabilitációról, és talán tematikusan a lakótelepek vásárlási szokásai kevésbé illettek bele a válogatás társadalmiszociológiai irányzatába.

Rövid hozzászólásomban három problémát kívánok érinteni: 1. a városrehabilitáció hogyan illett bele a szocialista városmodell elméletébe; 2 . mennyiben törte meg a rendszerváltás a rehabilitációs programokat, azaz az új feltételek menynyiben módosították a városrehabilitáció folyamatait; és végül 3. milyen társadalmi következményei vannak a kilencvenes évek végén felgyorsuló, belső városrészekben kialakuló programoknak.

A városrehabilitáció programját már az 1970-es évek közepén kidolgozták, de a program ténylegesen csak az 1980-as évek második felében indult meg, és akkor készuilt el az első tömb a VII. kerületben. A városrehabilitáció tulajdonképpen nem illett bele a klasszikus szocialista városfejlödési modellbe, amelyet elsősorban a tömeges lakásépítés és az ipar (gazdaság) területi igényét biztosító városfejlesztési politika jellemzett. A városrehabilitáció alárendelödött a lakáspolitika mennyiségi igényeinek, amelybe a magas szanálási arányú városfelújítási programok nem illettek bele. A nyolcvanas évek azonban már nem képviselték a klasszikus szocialista modellt ${ }^{1}$. A késöi szocialista társadalmi rendszerben - és ez különösen igaz a magyarországi fejlödési pályára - megjelentek a repedések: a magánszektor fokozott súlya, telekpiaci folyamatok fokozott szerepe, az állami és magánérdekek átfedése stb.). A rehabilitációs koncepciók (mint amilyen például a VI. kerület piaci alapú rehabilitáció koncepciója volt) pontosan ezekben a repedésekben jelentek meg. Mindazonáltal sem jogi, sem intézményi feltételei nem voltak meg annak, hogy a folyamat nagyobb mértékben beinduljon. A tömbrehabilitáció társadalmi hatásait jól jellemzi, hogy az egyetlen, teljesen átépített (15.) tömb lakásaiba a magasabb státuszú társadalmi csoportokba tartozók költözhettek, egyfajta irányított 
dzsentrifikáció eredményeképpen. (A lakások 70\%-át a rehabilitációs iroda osztotta el, 30\%-a pedig központi kijelölésủ volt ${ }^{2}$.) A késöi szocialista városrehabilitáció nem volt finanszírozható, ahogy az egész bérlakásrendszer sem: az 1987-es közösségi tulajdonú lakásépítés és üzemeltetés támogatásának költségvetési tétele $25 \mathrm{Mrd} \mathrm{Ft} \mathrm{volt,} \mathrm{mai} \mathrm{áron} 350 \mathrm{Mrd} \mathrm{Ft}$.

A rendszerváltás, értékelésem szerint, nem törte meg a rehabilitáció folyamatát, mert az be sem indult, és a nyolcvanas évek késỏi szocialista városmodellje nem volt felkészülve egy nagyobb léptékü városrehabilitáció megvalósítására. A rendszerváltás részben megteremtette a városfejlődés piaci környezetét (új magánszereplökkel, mint bankok, fejlesztök, befektetök stb.), részben pedig átalakította a város müködésének intézményi feltételeit, amelyeken belül a városrehabilitáció szempontjából talán a legjelentósebb szerepe a lakásprivatizációnak és, a főváros esetében, a decentralizációnak, nevezetesen a (túlzott) kerületi önállóságnak volt. Több írás is elemzi, hogy ez utóbbi két tényezö milyen nagymértékben akadályozta a rehabilitációs folyamatokat. A kötet rehabilitációval foglalkozó tanulmányai túlságosan elvesznek a leíró részletekben, és elhanyagolják a városszerkezet alakulását befolyásoló makrogazdasági és makroszociológiai kereteket. A városrehabilitáció mögötti alapkonfliktust az ún. ",telekár-rés",3 elmélet segítségével ragadhatjuk meg, amit úgy definiálhatunk, mint amely szerint a lakásállomány az infrastruktúra elavulásával és a városi funkciók változásával viszonylag jó városszerkezeti elhelyezkedésủ területek tényleges hasznosítása és az adott területek potenciális hasznosítása közötti különbség. A szocialista városfejlódésben a telekár-rés nem játszott közvetlen szerepet, mert a telekpiac nem befolyásolta közvetlenül a döntéshozók viselkedését - nem játszott közvetlen szerepet a programok megítélésében. (A késői szocialista várospolitikában egyfajta árnyékár már befolyásolta az állami döntéseket.) A rendszerváltás után azonban a telekár-rés alapvetô szerepet játszott a szereplök viselkedésében, sőt, mondhatjuk, hogy a városfejlődés motorjává válik a különbözö szereplöknek az a törekvése, hogy a telekár-résböl való részesedésüket maximalizálják. (Az irodapiac, a bevásárlóközpontok fejlesztésében is szerepet játszik ez a szempont.)

A telekár-rés elosztásának konfliktusa szempontjából a különbözö kerületi rehabilitációs stratégiák közötti különbség majdnem elhanyagolható, hiszen többnyire arról van szó, hogy mennyire "hatékonyan” lehet ezt a fejlesztési értéket kitermelni egy-egy területböl. Világos, hogy minél „rosszabb” egy terület lakásállománya (alacsony beépítési sürủség, alacsony értékủ lakások), és minél jobb elhelyezkedésü, annál nagyobb a telekár-rés. Következésképpen a területi stratégiák abban különböztek egymástól, hogy 1. mennyire voltak képesek egyáltalán realizálni a fejlesztési lehetöségeket; 2. milyen intézményi megoldások segítségével szabadítottak fel teruleteket a potenciális befektetők számára.

A kérdés az, hogy az adott intézményi, politikai és gazdasági feltételek esetében egyes kerületek milyen hatékonyan teszik lehetővé a telekár-rés realizálását. Az elmúlt évtizedben több évre volt szükség, míg az intézményi megoldások kialakultak, és a lakásprivatizáció és a kerületi önállóság csak nehezítette az érdekek (befektetö, bent lakó tulajdonos és bérlö, bankok, önkormányzatok, nonprofit városvédỏ szerve- 
Tér és Társadalom 20. évf. 2006/3. 109-158. p.

zetek stb.) egyeztetését. A tanulmányok részletesen leîrták ezt a folyamatot, amihez további két észrevételt szeretnék füzni. Egyrészt az eddigi rehabilitációs programok a beépíthetö üres telkek elöállítására koncentráltak, ebböl a szempontból, pl. a IX. kerület és a VIII. kerület alig különbözik egymástól, hiszen mind a két területen kb. 1:3 az aránya a lebontott és az új építésú lakásoknak. Sok szempontból tulajdonképpen inkább rekonstrukcióról és nem rehabilitációról beszélhetünk. Másrészt pedig a résztvevők racionális viselkedése esetén is (ami sajnos nem minden esetben jellemzó) komoly problémát okoz, hogy az egyéni (rövid távú) érdekek maximalizálása nem vezet társadalmi hasznok maximalizálásához (piaci kudarcok problémája), aminek a következménye, hogy történelmi értéket is képviseló városrészek tünnek el. (Lásd zsidó negyed és az Óvás Egyesuilet.)

Véguil pedig még egy kérdést szeretnék felvetni: milyen társadalmi következményekkel jár a városrehabilitáció? A kötet jól illusztrálja a városföldrajz és városszociológia adósságát a folyamatok leírásában, a hipotézisek tényekkel való ellenörzésében. A tanulmányok egyértelmủen úgy foglalnak állást, hogy a rendszerváltás után növekedett a lakóhelyi elkülönülés Budapesten, és megjelent az etnikai szegregáció, nevezetesen a roma lakosság térbeli koncentrációja. Ugyanakkor nagyon keveset tudunk arról, hogy a kilencvenes évek szuburbanizációja és a 2000 utáni felfutó fővárosi lakásépítés hogyan befolyásolta a város társadalmi szerkezetét. $\mathrm{Az}$ elemzök ritkán veszik figyelembe a lakáspiac egészének hatását, például azt, hogy a lakástranzakciók (tulajdonos és bérló változás) kb. 3-5-szöröse az új lakásépítésnek. Továbbá a költözéseket nem kizárólag az új lakások építése, és az ezekhez kapcsolódó tranzakciók alkotják, hanem a társadalom elöregedésével és a lakáshelyzet (100 háztartásra jutó lakások száma) javulásával a demográfiai megüresedés (elhalálozás miatt megüresedett lakások) fontos tényezövé vált: nagyságrendileg az így megüresedett lakások elérik az új lakásépítés 60-80\%-át. Erős a sztereotíp gondolkodás hatása: a fiatal, magas jövedelmủ és magas iskolai képzettségű csoportok kiköltöztek Budapeströl, a leromlott városrészekben pedig növekedett a szegregáció, a roma népesség egyre inkább koncentrálódik stb. Söt, a magyarázatok - ha vannak, akkor tendálnak egyfajta konspirációs elmélet felé, amelynek a lényege, hogy a gazdagok és az ö képviselőik, az önkormányzatok elüldözik a szegényeket. A következtetés társadalmi kritikájával teljes mértékben tudok azonosulni, én is úgy gondolom, hogy a folyamat egyik eredménye, hogy a szegények (köztük jól láthatóan a romák) kikerülnek a területről. De szociológusként úgy gondolom, hogy ezek a következmények alapvetôen strukturális okokra vezethetők vissza, ahol bizonyos körülmények és az egyéni, illetve intézményi érdekek miatt az egyes szereplök racionális döntései vezetnek el az ismert következményekhez. A Tér és Társadalom speciális számában található tanulmányok rámutatnak ezekre az összefủggésekre, de úgy érzem, hogy a lakáspiaci összefüggések nem kaptak kellỏ figyelmet, nevezetesen a fenntartható ${ }^{4}$ szociális bérlakásszektor hiányának ténye. E nélkül a szociális városrehabilitáció illúzió marad, hiszen a legszegényebb rétegeknek nem tudja biztosítani a lakhatás biztonságát, emiatt a kiegészítỏ programok (oktatás, munkaerö-piaci stb.) eredményei bármikor megkérdőjeleződhetnek. 
Összefoglalva, a kötet nagymértékben hozzájárult a városrehabilitáció folyamatára vonatkozó tudásunk gyarapításához, és remélhetőleg ösztönzést ad arra, hogy a kutatások egymás eredményeire jobban támaszkodva, az elméleteket és a tényeket szembesítő szakmai párbeszéd alakuljon ki.

\section{Jegyzetek}

${ }^{1}$ Lásd R. A. French, F. E. lan Hamilton The Socialist City: Spatial Structure and Urban Policy.

${ }^{2}$ Lásd Hegeduis J.-Tosics 1. (1991) Gentrification in Eastern Europe: The case of Budapest - Urban Housing for the Better-Off: Gentrification in Europe, Jan van Weesep and Sako Musterd (eds), Stedelijke Netwerken, Utrecht, The Netherlands. 124-136. o.

${ }^{3}$ A rent-gap elméletröl lásd N. Smith 1995, The new urban frontier. Routledge, 710.

${ }^{4}$ Mind az önkormányzat, mind pedig a valóban rászoruló házlartások által finanszírozható, elfogadható minöségü bérlakússzektor. 